\title{
Sisterly Conflict: Music and Text in Richard Strauss' Elektra (1909)
}

\author{
David G. Molina \\ Universidade de Chicago \\ davidmolina@uchicago.edu \\ https://orcid.org/0000-0001-7252-432X
}

\begin{abstract}
This paper undertakes a careful musical and lyrical analysis of Chrysothemis' first interaction with her sister ("Elektra!/Ich kann nicht sitzen und ins Dunkel starren") in Richard Strauss and Hugo von Hofmannsthal's 1909 opera Elektra. The paper's fundamental claim is that Chrysothemis is portrayed differently by Strauss and Hofmannsthal: where the text brings the sisters together by means of a crosspollination of images that emphasizes their shared heritage as daughters of Klytämnestra, the music - through abrupt shifts in style, melodic development, and harmony - prefers to present the sisters in diametrically opposing poles with respect to the family tragedy. By way of exploring the tensions between music and text in Elektra, the paper also investigates the ontological status of Klytämnestra's leitmotifs as they come into view and argues that proper classification of their role - as well as an understanding of leitmotivic perspectivism - is essential in diagnosing an imbalance of power between Elektra and Chrysothemis vis-à-vis the orchestra.
\end{abstract}

Keywords: Richard Strauss, Elektra (1909), Chrysothemis, Perspectival leitmotif, Music and text.

\section{Irmãs em conflito: música e texto em Elektra (1909) de Richard Strauss}

Resumo: Este artigo analisa a primeira conversa de Chrysothemis com sua irmã ("Elektra!/Ich kann nicht sitzen und ins Dunkel starren") na opera Elektra (1909) de Richard Strauss e Hugo von Hofmannsthal. O artigo identifica uma tensão entre música e texto na caracterização da personagem Chrysothemis: enquanto o texto de Hofmannsthal tende a aproximar as irmãs ao utilizar imagens que aludem à herança familiar comum a ambas, a música de Strauss - por meio de mudanças de estilo e desenvolvimento harmônicomelódico - apresenta as irmãs em polos diametralmente opostos diante da tragédia familiar. $\mathrm{O}$ artigo também investiga a ontologia dos leitmotifs de Klytämnestra, cuja utilização perspectival diagnostica uma desigualdade de poder entre Elektra e Chrysothemis em relação à orquestra.

Palavras-chave: Richard Strauss, Elektra (1909), Chrysothemis, Leitmotif perspectival, Música e texto.

Defining the ontological role of instrumental music is a perennial interpretative concern for those interested in exploring the at times symbiotic, at times conflicting interactions between music and text in works of opera. The fundamental problem, here - one that plays a crucial role in the work of scholars as different as Peter Kivy and 
Richard Taruskin ${ }^{1}$ - concerns the problem of "content" in instrumental music. If instrumental music has the capacity to impart unto its listener specific emotions or moods, and can fundamentally alter the textual material with which it interacts - if it is capable (as we know it is) of transforming the same line of text from serious to ironic depending on the style, key and rhythmic arrangement of notes on the staff - then it must, independent of program or accompanying text, possess a kind of non-discursive meaning that musicologists can identify and translate (into words) in their scholarly work. If the meaning of an operatic libretto is changed by the music that accompanies it, then it follows that there must be something in the music, some "information" that brings about that interference. Unlike other arts, in music, characterizing this content is difficult to do. If literature deals - albeit in distorted or altered form - with the complex web of linguistic signs we use to communicate thought in speech, the "content" of tonal absolute music must have something to do with lower or higher structural hierarchies, repetitions, and the horizontal and vertical positioning of notes relative to one another and to their respective keys.

The problem of musical content is important not because of an essentializing compulsion - a need to define what music is in itself, independent of other arts - but for its role as the mysterious second element in the much more familiar study of the interactions between text and music in opera. Operatic librettos have plots, tell stories, communicate ideas and express emotions, and despite all of these functions, most operagoers would probably agree that it is the music that primarily shapes their experience, providing crucial insights into the action unfolding on stage. Attending to how musical content bears on characters, mise-en-scène and plot is at the heart of the phenomenology of the opera experience, and most fans, I would argue, would not be hard-pressed to produce the following categories of music and textual interaction:

1. Representation - the "standard leitmotif," when an orchestral theme is understood to stand for or otherwise represent a particular character, object or idea;

\footnotetext{
${ }^{1}$ In Kivy's exploration of the relationship between music and ethics, the problem of musical content appears in its negation, that is, he denies that there is such a thing in order to then deny that music can shape ethical perception of events in one way or another (KIVY 2009); Taruskin, in effect, argues the very opposite: by pointing out situations where this elusive musical content has been and is harmful to particular individuals or populations, he claims that it might be powerful enough to justify censorship of certain works and performances (TARUSKIN 2008).
} 
2. Mood creation, where orchestral music sheds light into a character's mind (or world) by inciting particular emotional responses from the audience;

3. Contrast, when the orchestral music is employed to ironic effect by communicating emotions that run contrary to the tenor of the interactions unfolding on stage;

4. Diegesis, where the orchestral music is itself heard by the characters on stage, who in some way respond to it.

Considering that instrumental music is usually thought to be non-narrative, that is - without a program, it can be thought to tell a story only metaphorically or through the occasional mimetic evocation of natural sound that does not, in a straightforward sense, constitute story or plot - it is not surprising that musicologists have mostly shied away from seriously considering, in music, analogues to the literary problem of point of view. Can the orchestral music of an opera, in a non-metaphorical sense, be said to communicate a point of view or perspective on the narrative described? And furthermore, could that point of view be shown to be - as it often is, in literature - not a "view from nowhere" but something like the unreliable first-person accounts of Vladimir Nabokov?

In this paper, I undertake a careful musical and lyrical analysis of Richard Strauss' 1909 opera Elektra by focusing on the fundamental divergences in how the character Chrysothemis, Elektra's sister, is characterized by Strauss and librettist Hugo von Hofmannsthal. Where the text brings the sisters together by means of a cross-pollination of images that emphasizes their shared heritage as daughters of the degenerate Klytämnestra, the music - through abrupt shifts in style, melodic development, and harmony - prefers to present the sisters in diametrically opposing poles with respect to the family tragedy. By way of exploring the tensions between music and text in Elektra, the paper argues that the orchestral writing in the opera is marked by a kind of "perspectivism" - where the melodies and accompanying harmonies act as manifestations of Elektra's voice in a matter that evokes first-personal narration - that is essential in diagnosing a fundamental imbalance of power between Elektra and Chrysothemis vis-àvis the drama. The paper, thus, takes Elektra's diagnosis of the orchestral music in her final maenadic dance - "Ob ich die Musik nich höre? Sie kommt aus mir" ("How could I not hear the music? It's coming from me") - not as delusional madness, but as a literal depiction of Strauss' leitmotivic writing: in Elektra, the orchestra is Elektra's. 


\section{Three Elektras: Sophocles, Hofmannsthal, Strauss}

The extraordinary impact of Richard Strauss' Elektra (1909) on the music of the $20^{\text {th }}$ century is perhaps best encapsulated by an oft-quoted line by Igor Stravinsky: "Since Parsifal there have been only two operas, Elektra and Pelléas" (STRAVINSKY in CRAFT, 1977, p. 91). While praise from Stravinsky might have been enough to call attention to any musical work, the impact of the line - and hence its widespread popularity in the literature on the opera - is a result of the Russian's well-known dislike of Strauss and his music. ${ }^{2}$ If even Stravinsky thought Elektra was worth his time, the argument goes, it deserves pride of place in the German composer's musical trajectory. Stravinsky's reaction was not a solitary one. Noteworthy critics such as Carl Dahlhaus and Theodor Adorno - no admirers of Strauss - single out Elektra in their writings. If the former devotes three pages to the work in his history of nineteenth-century music, ${ }^{3}$ the latter describes the dialogue between Elektra and Klytämnestra as the pinnacle of Strauss' musical writing. ${ }^{4}$

As fascinating as the music itself, however, is Strauss' collaboration with librettist Hugo von Hofmannsthal. While the opera's plot is mostly faithful to the original Sophoclean drama, the character of the work is decidedly more modern, and Hofmannsthal's dark style does much to imbue the characters with added dramatic and psychological dimensions ${ }^{5}$. Part of the extreme reactions to Elektra's first performances - denounced in Dresden and widely celebrated in London - is a result of Hofmannsthal's writing, which draws attention to, among other things, the role of women in society, the

\footnotetext{
${ }^{2}$ For an example see PUFFETT 2001, p. 398.

${ }^{3}$ See DAHLHAUS, 1980, p. 291-293. In the spirit of the analysis that follows is the following statement, by Dahlhaus: "Denn so nachdrücklich das Agamemnon-Motiv den Namen des Königs instrumental deklamiert oder das Ägisth-Motiv den heuchlerischen Gestus des Königsmörders musikalisch illustriert, so unverkennbar ist es auch, daß einem Motiv erst in den wechselnden Zusammenhängen, in die es durch den musikalischen wie den dichterischen Kontext gebracht wird, seine eigentliche Bedeutung allmählich zuwächst, und daß umgekehrt von dem Sinn, den ein Motiv in sich trägt, wiederum Licht auf die Umgebung fällt, in der es erscheint. Eine Interpretation der Leitmotivtechnik, die den Namen zu verdiene trachtet, müßte also vom Prinzip der kommentierten Thementafel zu dem hermeneutischen Bemühen übergehen, den Gehalt der Motive in den Wandlungen, denen er unterworfen ist, aufzusuchen" (p. 291).

${ }^{4}$ Stale Wikshaland characterizes the Adorno-Strauss relationship thusly: "Theodor W. Adorno claimed that Strauss was the perfect image of the aesthetic enemy, one who, if he had not been on hand, would have had to be invented" (WIKSHALAND, 2007, p. 166). For Adorno on Elektra, see ADORNO, 1956, p. 56-57.

${ }^{5}$ For a detailed discussion of the differences in style and worldview between Hofmannsthal and Sophocles -including the crucial absence, in the opera, of Sophoclean Sittlichkeit - see WIKSHALAND, 2007.
} 
logical character of anger and revenge, and the adequacy of one's response to family death.

Character development - both musical and lyrical - is a special virtue of Elektra. As examples, one could cite the musical reinvention of the character of Klytämnestra - who appears in the opera as a selfish, blood-thirsty insomniac whose moral and physical decay emanates from the music written for her - and the famous recognition scene, where music and text work together to reunite Elektra and Orestes, imparting unto them the necessary resolve to carry out their murderous intent. The characterization of Elektra's younger sister Chrysothemis is equally fascinating. Although scholarly treatment of her character has, thus far, been incompatible with her considerable role in the opera, Chrysothemis' narrative position - in particular her stance with respect to Elektra - is carefully crafted by Hofmannsthal and Strauss. It is this relative dearth of discussion on Chrysothemis - and on the Chrysothemis-Elektra relationship - that this paper seeks, in part, to remedy. ${ }^{6}$

The insertion of Chrysothemis into the myth of Elektra is a Sophoclean contribution. ${ }^{7}$ In contrast to versions by Euripides and Aeschylus - in which Iphigenia and Orestes are Elektra's only siblings - Sophocles introduces Chrysothemis with the hopes of providing a foil to Elektra in the younger sister's more conventional, placatory nature. By introducing a character with more mundane ambitions (Chrysothemis aspires to get married and have children), Sophocles emphasizes the one-mindedness of his protagonist, a woman unable to think of much besides revenge (in Antigone, that role is played by Ismene). The Sophoclean Chrysothemis also introduces a crucial conflict between the sisters: namely, that neither Elektra nor her sister is allowed to get married unless violent retribution is exacted from Clytemnestra and Aegisthus. This restriction forces the sisters to confront one another, a feature of the tragedy that is extended and developed by Hofmannsthal in the opera libretto. The "standard" dramatic view of

\footnotetext{
${ }^{6}$ There are, of course, important exceptions to this trend, the most important of which is Sonja Bayerlein's Die Drei Frauengestalten in der Opera Elektra (BAYERLEIN, 1996).

${ }^{7}$ I should note, however, that Chrysothemis is not Sophocles' creation. She is listed as one of the daughters of Agamemnon as early as Book 9 of Homer's Iliad.
} 
Chrysothemis can be characterized thusly: she underscores the intransigence of her sister by embodying an alternative approach to the family tragedy. ${ }^{8}$

Careful attention to Hofmannsthal's libretto, however, suggests a more complex relationship between the sisters in the opera. Although the characters' motivations appear radically different - one sister seeks fulfillment in death while the other in motherhood and love - Hofmannsthal's text also establishes important similarities between Chrysothemis and Elektra. Crucial to this approximation is the sisters' shared heritage as daughters of Klytämnestra, whose character and voice speaks through her children in select moments in the work.

Most puzzling of all, however, is the fact that Strauss' music - in particular the harmonic and melodic choices associated with each sister - often ignore Hofmannsthal's lyric ambiguity in favor of a foiling or contrasting approach. ${ }^{9}$ As far as the sisterly bond is concerned, thus, libretto and music in Elektra are often in tension with one another. Consider for example one of the most important Chrysothemis-Elektra scenes in the opera: "Elektra!/Ich kann nicht sitzen und ins Dunkel starren/Es geht ein Lärm los."

As Elektra's famous solo "Allein! Weh, ganz allein!” fades into the background, Chrysothemis, the younger sister, appears before the doorway of the palace and calls to Elektra in a pathetic musical phrase that surfaces in developed form later in the opera. After retelling the murder of Agamemnon in gruesome detail and, in a trance-like waltz, fantasizing about the categorical defeat of Klytämnestra and Aegisthus, Elektra "wakes up" (as Hofmannsthal's libretto indicates) to her sister's face, an image that provokes a sense of revulsion and disgust. As if to underscore the move from daydream to reality, the lines "Ah, das Gesicht!" are preceded by a polytonal E - C-flat - D-flat - F - A-flat

\footnotetext{
${ }^{8}$ This position is perhaps most keenly communicated by Richard Chessick in his summary of the opera "Another important character, her sister Chrysothemis, is a split-off narcissistic twin opposite image of Elektra. She wants to be a woman with a husband and children, and she represents the traditional themes of femininity, childbearing, and the life force or Eros" (CHESSICK, 1988, p. 585-596). A version of it also articulated by Strauss biographer Norman del Mar (DEL MAR, 1962, p. 294-295).

${ }^{9}$ On the issue of the musical contrast between the sisters, Bayerlein cites an excerpt from Strauss in which he explicitly claims that one of the "points of attack" of his opera is the constellation "ElektraChrysothemis", the "demonic rage-goddess against the luminary figure of her earthly sister" ("die dämonische Rachegöttin gegen die Lichtgestalt ihrer irdischen Schwester" umschreibt"). STRAUSS in BAYERLEIN, 1996, p. 171.
} 
in the brass that is transformed into a suspended chord consisting of two minor triads: D - F-sharp - B and C - F - A-flat (Fig. 1, rehearsal mark 64). ${ }^{10}$

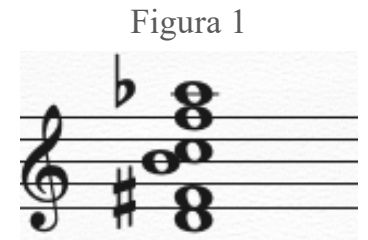

Fonte: STRAUSS, Elektra, Dover Publications, 1991, rehearsal mark 64.

Since a similar juxtaposition of triads - in the latter case, major - is employed by Strauss in the subsequent scene (the scene where Klytämnestra describes her nightmares), it is possible to infer that Strauss means the listener to associate this form of polytonality with the transition between waking and dreaming. The similarity in the harmonic structures also serves to establish an initial parallel between Elektra and her mother, a feature of the narrative frequently exploited in the Hofmannsthal libretto.

The very first line uttered by Elektra to her sister, however, already begins to complicate our understanding of Chrysothemis as a foil to Elektra. The visceral hatred expressed by "Ah, das Gesicht!" is palpable, but its motive is ambiguous. What is the reason for such profound aversion? Here are a few possibilities:

1) Chrysothemis' face inspires hatred for it metonymically stands for Chrysothemis herself, whose choice to continue living in the house of her murderous mother is despicable to Elektra;

2) Chrysothemis' face is painful to Elektra to the extent that it evokes the face of Agamemnon, whom she desperately wishes would reappear before her;

3) Chrysothemis reminds Elektra of Klytämnestra's appearance, a resemblance that inspires Elektra to project her hatred for her mother onto the younger sister. ${ }^{11}$

Of these possibilities, the remainder of the scene best supports options 1 and 3 : Elektra is upset at Chrysothemis for continuing to inhabit an environment that is morally stifling, and Elektra's line "Tochter meiner Mutter, Tochter Klytämnestras," referring to Chrysothemis, can be understood as a statement of a physical as well as moral resemblance between mother and daughter. Although the primary purpose of this opener

\footnotetext{
${ }^{10}$ DEL MAR, 1962, p. 304.

11 Sonja Bayerlein offers yet another possibility: that Elektra averts her eyes from her sister because Chrysothemis, like Klytämnestra, places sexual fulfillment at the heart of her personality. See BAYERLEIN 1996, p. 80.
} 
is to nominally establish Elektra and Chrysothemis in two distinct poles with respect to the family tragedy - the hatred of one for the other serving as the divisive force between them - this strict separation continues to be lyrically undermined by two later moments in the duet. The first, and perhaps most intriguing, is the already cited line "Was willst du? Tochter meiner mutter, Tochter Klytämnestras?"

Many commentators have noted that this line represents a collaborative achievement of Strauss and Hofmannsthal. In the earliest versions of the text, Hofmannsthal chose not to employ character names - like Agamemnon and Klytämnestra - in order to imbue them with added gravitas when finally uttered. Hofmannsthal's aim, it seems, was to give names the almost mystical power of - if not physically, at least spiritually - summoning a character onto the stage. In letters to Hofmannsthal, Strauss demanded that names be reintroduced into the opera for two reasons: 1) he felt the literary device would not translate well into music; and 2) he thought the plot might become unnecessarily confusing without reference to key figures like Agamemnon and Klytämnestra. ${ }^{12}$ I would claim that Strauss' aim in reinserting the names was primarily leitmotivic: not only do leitmotifs accompany names throughout the score, but in the case of Agamemnon, the very rhythm of his name is the inspiration for the melodic material in Elektra's monologue (Fig. 2, measures 1-3). ${ }^{13}$

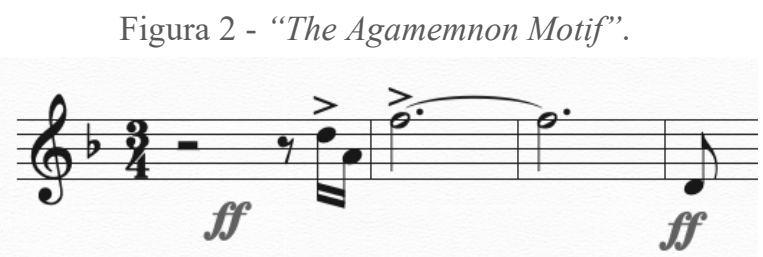

Fonte: STRAUSS, Elektra, Dover Publications, 1991, mm. 1-3.

\footnotetext{
${ }^{12}$ Discussion of this point can be found in both PUFFETT, 1989, p. 33 and DEL MAR, 1962, p. 296-298.

${ }^{13}$ This point is more fully investigated by Derrick Puffett. Puffett claims not only that the insertion of names in the opera serves as inspiration for the leitmotifs themselves, but also emphasizes their structural role as refrains in various scenes throughout the work. Strauss frames Elektra's monologue, for example, with two double statements of "Agamemon!" adding two single statements around the mid-point. (PUFFETT, 1989, p. 33-35). Wikshaland's reading of the named motifs is also worthy of note: "The Agamemnon theme carries us with one blow to another place and to another time. And this time it breaks through to the present by conjuring up the past, which is evoked by feeding upon the listener's imagination. It is a type of theme that virtually can't be forgotten, a theme saturated with all the weight and expression that is absent in the preceding musical squabbling, a theme that suddenly grounds the scene as a whole in itself. This is music strong enough to create a world of its own, the world of Elektra's reality" (WIKSHALAND, 2007, p. 168169).
} 
At first, then, "Tochter meiner mutter" appears to establish a relationship between Chrysothemis and Klytämnestra, as if the moral failings of the mother somehow tainted the character of the daughter. This is achieved, of course, by the genitive "daughter of my mother," "daughter of Klytämnestra," phrases that emphasize Klytämnestra's possession of Chrysothemis, or, alternatively, Chrysothemis' capitulation to the power of the mother. It is clear, here, that Elektra - perhaps unfairly - associates Chrysothemis with the murderous side of the family, implying that by remaining in the house, the sister is somewhat complicit in the assassination of Agamemnon. Hofmannsthal himself furthers this connection by ensuring that the first entrances of Chrysothemis and Klytämnestra in the opera "rhyme situationally", that is, they are not identical, but share enough commonalities to be understood as a pair. Key similarities between the scenes include: the fact that Chrysothemis and Klytämnestra are both tormented upon arriving (by the impossibility of marriage and nightmares, respectively); the fact that they are both greeted by a hissing Elektra and the "Hatred motif"; and the fact that they both are in some sense barren (Klytämnestra describes herself as a "wasteland" while Chrysothemis complains she has no children).

The crucial ambiguity of the statement, however, is provided by the word "meiner." If one emphasizes this term, the line transforms into a claim about Elektra and her relationship to Klytämnestra. Elektra, of course, is also "daughter of her mother," a fact that would imply that the despicable "Klytämnestraness" she recognizes in her sister might also be present in her. The line, hence, serves the dual purpose of presenting the audience with Elektra's reading of Chrysothemis - as an associate of Klytämnestra - and revealing a feature of Elektra's own character, namely, that she too inherits aspects of her progenitor's terrible personality. This possibility, of course, is more than confirmed as the opera unfolds. ${ }^{14}$ Similarity to Klytämnestra - or, at the very least, perceived similarity to Klytämnestra - serves to bring the sisters together at this early moment in the scene.

The next crucial ambiguity in the Chrysothemis-Elektra relationship is encapsulated by the line "Was hebst du die Hände? So hob der Vater seine beiden Hände, da fuhr das Beil hinab und spaltete sein Fleisch" ("Why lift up your hands, just as our father lifted up his two hands before the axe came down and split apart his flesh?"). Here,

\footnotetext{
${ }^{14}$ For a clear parallel between Elektra and Klytämnestra, see my subsequent discussion of the lines "Was hebst du die Hände?"
} 
Elektra compares her sister's reaction to the gestures of Agamemnon in the instances leading up to his murder. Once again, the interpretations of the line are many. In one reading, the line reveals a feature of Elektra's turbulent psyche. Elektra is so obsessive about her father's murder - she is constantly revisiting the bathhouse scene in her head that she imagines it everywhere, even in her sister's flinching gestures. A second reading, more relevant for the purposes of this analysis, is one in which the line establishes an identification between Klytämnestra and Elektra. If Chrysothemis' flinching is akin to Agamemnon's, then it follows that Elektra's aggression vis-à-vis her sister is not unlike that of her murderous mother.

Careful consideration of the music that accompanies this charged exchange, however, introduces significant interpretative difficulties. At the very start of the scene, for example, Elektra's revulsion at her sister's face is followed by an utterance of Elektra's "Hatred Motif" (Fig. 3, rehearsal mark 64-65), a short theme introduced at the very start of the opera that embodies Elektra's disregard for the five maids of the palace. Chrysothemis has not even spoken yet, and already Strauss underscores that Elektra sees Chrysothemis as little better than a servant. ${ }^{15}$

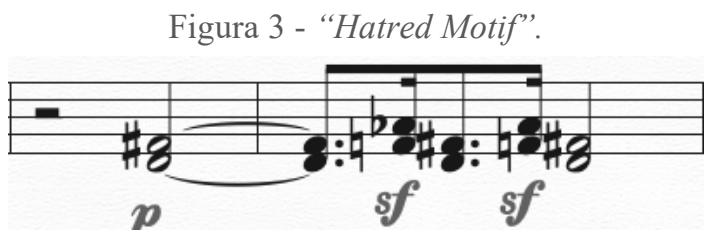

Fonte: STRAUSS, Elektra, Dover Publications, 1991, rehearsal mark 64-65.

Along with "Tochter meiner Mutter," Strauss's music features three (or four, depending on how they are counted) motifs associated to Klytämnestra (Fig. 4 rehearsal mark 66, Fig. 5 rehearsal mark 68, and Fig. 6 rehearsal mark 68-9). Strauss biographer Norman del Mar argues that these represent not so much Klytämnestra's strength and power, but her decay and sinister influence over others. ${ }^{16}$ What are we to make of this unexpected appearance of the Klytämnestra leitmotifs amidst the Chrysothemis-Elektra

\footnotetext{
${ }^{15}$ Although Bayerlein's approach to the first Elektra-Chrysothemis scene in the opera focuses more on the complementarity of music and text, she occasionally (and rightly) alludes to the tensions I emphasize here: “Trotz ihres Lebenstriebes ist auch Chrysothemis' Leben von Angstzuständen durchzogen, die Strauss zwar im Vergleich mit Hofmannsthals Text durch Kürzungen zurückdrängt, die jedoch in der musikalischen Charakterisierung von Chrysothemis durchaus ihre Entsprechung finden" (BAYERLEIN, 1996, p. 182).

${ }^{16}$ DEL MAR, 1962, p. 301.
} 
duet? In some sense, the leitmotifs seem representational, for they are accompanied by specific mentions of Klytämnestra's name; this association enables us to establish parallels between music and text even before Klytämnestra appears on stage. However, a different view might also be possible, one that could preclude the need for Klytämnestra to appear on stage entirely: what if Strauss' musical motif is not an objective representation of Klytämnestra on the part of the orchestra but, a rendering of Elektra's view of her mother?

Figura 4 - "Klytämnestra Motif 1".

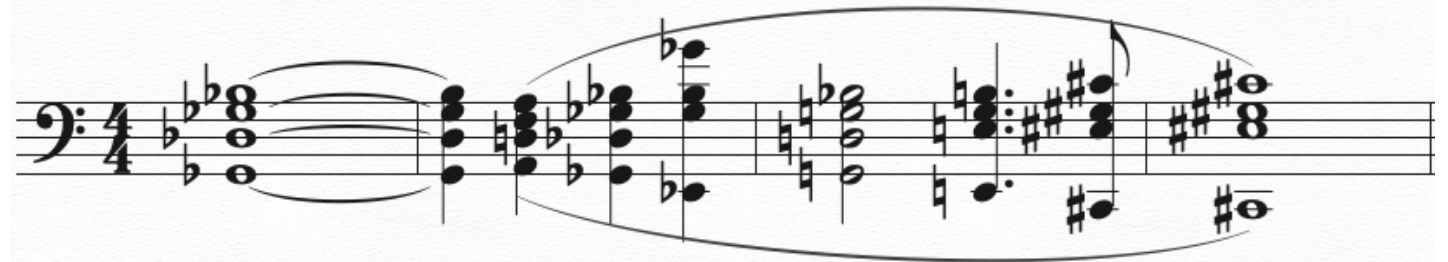

Fonte: STRAUSS, Elektra, Dover Publications, 1991, rehearsal mark 66.

Figura 5 - "Klytämnestra Motif 2".

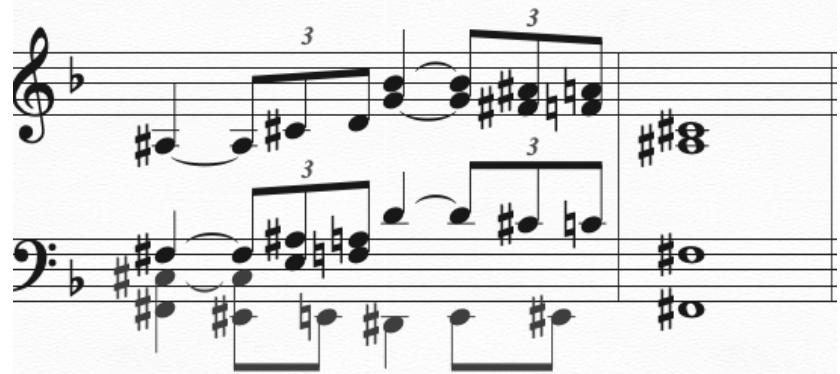

Fonte: STRAUSS, Elektra, Dover Publications, 1991, rehearsal mark 68.

Figura 6 - "Klytämnestra Motif 3".

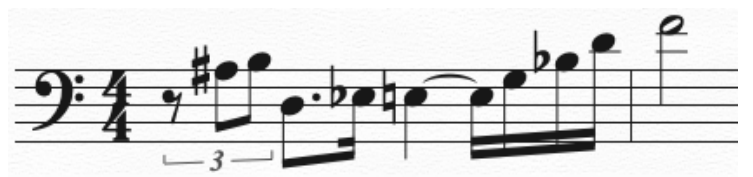

Fonte: STRAUSS, Elektra, Dover Publications, 1991, rehearsal mark 68-69.

The music suggests that at least one of the above leitmotifs is not independent of Elektra's psyche. For one, it is part of the very structure of Elektra (the opera and the Sophoclean play) that the action is inextricably tied to the lead character. Not only is 
Hofmannsthal's text almost exclusively concerned with her struggles and fantasies, but Elektra herself never leaves the stage.

Attention to the subsequent iteration of the leitmotif (Fig. 7), occurring around rehearsal mark 133, when Klytämnestra first appears on stage - can be used to settle the question. The motif - a stream of ascending sixteenth notes followed by repeated major thirds - is a reduction of two of Elektra's key motifs: "Elektra's Hatred" and "Elektra's Nobility" (Fig. 8 rehearsal mark 1, Fig. 9 rehearsal mark 17). Here, Strauss shows us that this characterization of Klytämnestra is, quite literally, derived from the music of Elektra. The motif, built upon musical material primarily associated with Elektra herself, is hence not an objective rendering of the mother, but how she stands from Elektra's musical point of view.

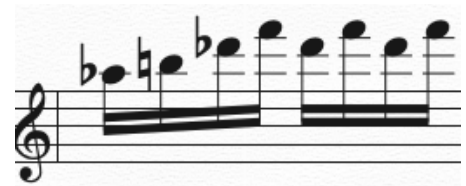

Fonte: STRAUSS, Elektra, Dover Publications, 1991, rehearsal mark 133.

Figura 8 - "Elektra's Hatred 2".

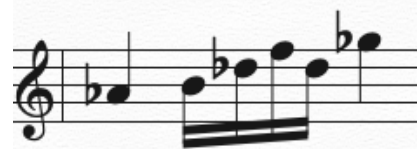

Fonte: STRAUSS, Elektra, Dover Publications, 1991, rehearsal mark 1.

Figura 9 - "Elektra's Nobility".

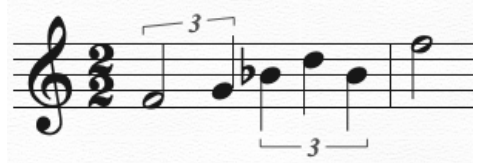

Fonte: STRAUSS, Elektra, Dover Publications, 1991, rehearsal mark 17.

The similarities in orchestration and melodic structures between the motif in Fig. 7 and Klytämnestra's third motif in the duet (Fig. 6) renders their common origin in the music of Elektra unmistakable. This motif (Fig. 6) voiced frequently by the woodwinds (especially by bassoon and flute) is clearly a foreshadowing of Fig. 7 in undeveloped 
form. That this is the case becomes perfectly clear if we remember that the motif in Fig. 7 had already been introduced (if only fleetingly) in the only reference to Klytämnestra in Elektra's opening monologue (near rehearsal mark 39). With the motif in Fig. 6, thus, Strauss offers us not a "view from nowhere" of Klytämnestra - a seemingly objective portrayal or evocation of her character - but Elektra's musical image of her mother which she also projects onto the younger sister.

Read this way, therefore, Strauss' leitmotivic writing glosses the text in a way that somewhat undermines its ambiguity. If careful readings of "Tochter meiner Mutter..." and "Was hebst du die Hände?" bring the sisters together by emphasizing their common ties to Klytämnestra, the perspectivism advances a more traditional foiling relation by creating a clear power hierarchy between the sisters. If Klytämnestra's leitmotifs are, as I claim, indeed manifestations of Elektra's first-personal point of view, then the audience is left entirely ignorant of Chrysothemis' take on her mother. ${ }^{17}$ In this view, our musical understanding of Klytämnestra (in this early moment in the opera, at least) is wholly mediated by Elektra. Strauss's music is divisive, thus, insofar as it gives only the title character the ability to express herself through the orchestra. Chrysothemis' orchestral silence characterizes her subservience: like Elektra herself, the Klytämnestra leitmotifs (whose origin, as shown, lie in Elektra's own music) act as assailants that render Chrysothemis powerless and mute. ${ }^{18}$

Following the duet's initial interchange is perhaps the greatest textual example of the interpenetration of ideas among the sisters. In an attempt to describe the degenerate moral state of the palace, Elektra relies on a metaphor of choking and lack of breath. She ultimately tells Chrysothemis that she should shut all the doors of the palace to prevent the stifled air from escaping into the outside world. This is, perhaps, a counterintuitive image. If the air inside is stifled, might one not want to open the doors and windows to

\footnotetext{
${ }^{17}$ For the purposes of this argument, I am relying on Elektra's permanence on stage throughout the opera to extend the perspectival nature of Example 6 to the other two motifs.

${ }^{18}$ Lawrence Kramer also remarks on the dynamics of oppression unfolding between orchestra and character in Elektra but chooses to focus, instead, on the lead protagonist. His text also points to what I've called a perspectival reading of the Klytämnestra leitmotifs: "As the action develops, unfolding continuously for some two hours without intermission, the opera becomes a kind of enormous Lied expressing Elektra's subjectivity. The shifting expressive focus basic to opera as a genre is arrested; what we hear is the musical equivalent of obsessional thinking, half by Elektra, half about her" (KRAMER, 1993, p. 144-145). Carolyn Abbate also makes a claim for the perspectivism of the famous "Agamemnon motif": "The thing for which the motive stands, in the classic semiotic sense, is not Agamemnon at all, but rather Elektra's voice; more specifically, the mourning lament that so strongly marks her existence" (ABBATE, 1989, pp. 107-27).
} 
relieve those inside from its asphyxiating grip? Not for Elektra. She, rather, imagines the palace as a hermetic space whose deadly air might force her mother and stepfather into despair or suicide. In a move not unlike the most dialogic scenes in Dostoevsky, however, Chrysothemis takes up Elektra's metaphor of lack of air and expands it, suggesting that, at least as far as the atmosphere inside the house is concerned - the sisters are on the same page. Says Chrysothemis: "Mir ist die Kehle wie zugeschnürt, ich kann nicht einmal weinen, wie Stein ist alles!" ("I feel my throat is tied up so much that I can’t even cry, all's turned to stone!")

Hofmannsthal puts forth yet another parallel between the sisters, here. When Chrysothemis says "Ich kann nicht sitzen und ins Dunkel starren, wie du. Ich hab's wie Feuer in der Brust" ("I cannot sit here staring into darkness, like you. I have a fire in my breast"), she appears to be introducing a fundamental distinction between the sisters: Elektra stares into darkness outside while Chrysothemis has a fire in her breast that makes her restless inside. A second read reveals, however, that Chrysothemis' claim reflects a misunderstanding of Elektra's role within the opera. While the protagonist does indeed skulk around the palace walls, she is far from passive; in fact, it is the "fire in her breast", the fire of revenge, that motivates her every action. Hofmannsthal underscores this similarity much later in the opera when, during her final Maenadic dance, Elektra tells Chrysothemis: "Ich war ein schwarzer Leichnam unter Lebenden und diese Stunde bin ich das Feuer des Lebens und meine Flamme verbrennt die Finsternis der Welt" ("I was a black cadaver in the living, but this very moment I am the fire of life and my bright flame lights up the darkness of the world.") Elektra becomes self-consuming fire. By taking up one another's metaphors of suffocation and fire, thus, Elektra and Chrysothemis become not foils but doubles of one another as the opera unfolds ${ }^{19}$.

\footnotetext{
${ }^{19}$ I should perhaps note that although they share a sense of claustrophobia with respect to their family, Chrysothemis and Elektra disagree fundamentally about who deserves responsibility for this stifling predicament. For Elektra, blame lies with Aegisthus and Klytämnestra, who in killing Agamemnon destroyed the family order. What she is unable to see, however, is that the threat she poses to her mother and stepfather has enormous consequences for her sister, who wants to get married. Chrysothemis, thus, takes Elektra herself to be to blame for the torpor of her life. She sings "Du bist es, die mit Eisenklammern mich an den Boden schmiedet. Wärst nicht du, sie liessen uns hinaus." "Your influence: like an iron clamp it rivets me firmly captive. But for you they'd let us out of here) and "Wär' nicht dein Hass, dein schlafloses, urbändiges Gemüt, vor dem sie zittern, ach, so liessen sie uns ja heraus aus diesem Kerker, Schwester!" ("But for your hate, your tireless, inexorable drive, at which they tremble, ah, they'd surely let us get away from this foul prison, sister!")
} 
Strauss' music, however, does much to differentiate the sisters, here. If $\mathrm{C}$ minor is the key of Elektra's evocation of Agamemnon in her opening monologue - and C becomes the key of triumph in both vision and reality (the opera's final scene in also in C major) - Chrysothemis' theme (Fig. 10, rehearsal mark 75) appears in the relative key of E-flat major. If Elektra is indeed, as some commentators claim, structured as a vocal symphonic poem, then Chrysothemis is responsible for introducing the crucial B-theme of the drama, the counterposing voice to Elektra's A. ${ }^{20}$ Furthermore, the profound change in musical idiom provoked by the appearance of Chrysothemis' theme further advances a sense of estrangement between the characters. Del Mar remarks that Chrysothemis' motifs (Fig. 10 and 11, rehearsal mark 66) are strikingly conventional compared to the rest of the work and reflect, for him "the one weak section of the score." He also notes that Chrysothemis' traditionally romantic, lyrical lament (Fig. 11) is in harsh contrast with the spasmodic aggression of Elektra's speech. More than anywhere in the score, the conventional musical writing of Chrysothemis' music undermines the ambiguities of Hofmannsthal's text.

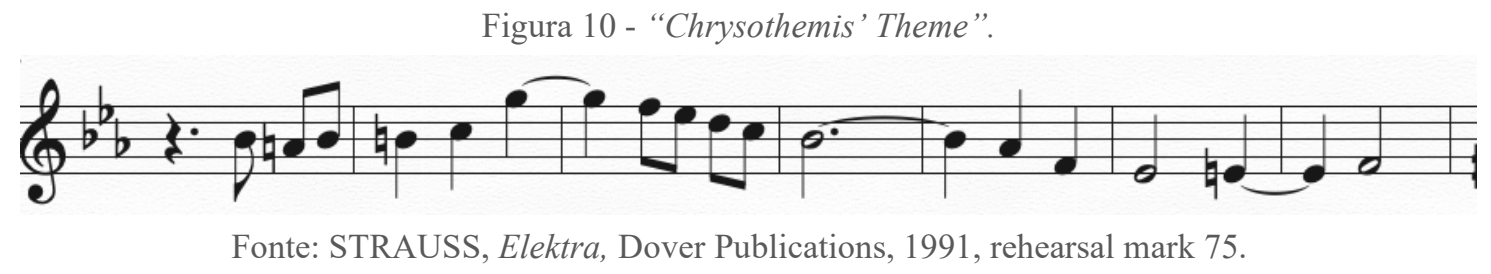

Figura 11 - "Chrysothemis' Motif".

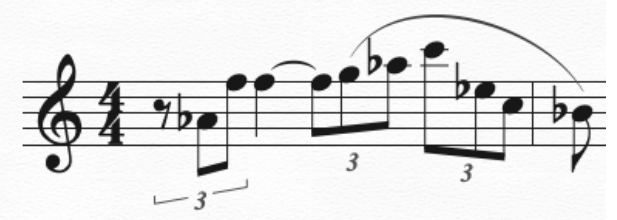

Fonte: STRAUSS, Elektra, Dover Publications, 1991, rehearsal mark 66.

It is also worth noting, as does Derrick Puffet, that Strauss made major changes to Chrysothemis' speech as it was originally laid out in Hofmannsthal's libretto. In the opera, the text unfolds as follows (I quote from Puffett):

\footnotetext{
${ }^{20}$ Norman del Mar is the primarily advocate of this position although Arnold Whittall also suggests a similar view. See WHITTALL in PUFFETT, 1989.
} 
1. In my breast there is a burning fire that sends me wandering round the house.

2. Were it not for you [Elektra], they would let us go.

3. I want to have children.

4. Our father is dead. Our brother does not come back.

5. One day after another engraves its passing with a knife in your face and mine... and women whom I have known slender are heavy with blessings, drag themselves to the well... and out of them flows sweet drink, and a living creature clings to them, sucking, and the children grow bit -

6. And forever we sit like caged birds... and no one comes - no brother, no messenger from the brother, no messenger from a messenger, nothing!

7. Much better to be dead than be alive and not live.

8. No, I am a woman and I want a woman's lot.

In Hofmannsthal's original, however, numbers 1-4 appear in the same order, but 58 have been rearranged: the order is $6,5,8$, then 7 . Strauss joins together similar thoughts - such as the death of the father, and the brother that does not return - allowing the rhetoric to build up to a climax devoted to wanting "a woman's lot". The result, says Puffett, is logically more conventional: Chrysothemis appears much less incoherent. Strauss' effort to distinguish Chrysothemis and Elektra was not merely limited to the music, thus, but also surfaces in his modifications to Hofmannsthal's text. ${ }^{21}$

The next crucial move in the sisterly relationship is brought out by Hofmannsthal's line: "Eh' ich sterbe, will ich auch leben! Kinder will ich haben, bevor mein Leib verwelkt, und wär's ein Bauer, dem sie mich geben; Kinder will ich ihm gebären und mit meinem Leib sie wärmen in kalten Nächten" ("Before dying, I want to live first! I want to have children before my body wilts. Were it a peasant whom they would give me, children I would gladly bear him, and I'd warm them to my bosom on wintry nights"). These words forge another intriguing parallel between Chrysothemis and Elektra, one that alludes to another version of the play, that of Euripides. Out of fear that Elektra's offspring might inherit her revenge, in that version, Clytemnestra and Aegisthus marry her to a peasant in Mycenae who vows to respect her virginity. In return for his kindness, Elektra assists her husband with household chores. Despite her appreciation for her life partner, however, Elektra resents being cast out of her house and laments to the chorus about her drastic change in social standing. In the opera libretto, Hofmannsthal invokes Elektra's marital woes in Euripides through Chrysothemis: she is willing to suffer a blow

\footnotetext{
${ }^{21}$ PUFFETT, 1989, p. 34.
} 
to her status if it means she can hold a child against her bosom. Whether it is possible for anyone in the house of Atreus to live out an ordinary family arrangement is the question that drives the tragedy of the passage: can someone in the line of Agamemnon, of Menelaus, of Tantalus achieve this sort of marital bliss? In including this reference to the peasant, Hofmannsthal encourages the reader to draw not only a direct parallel between the sisters - with Chrysothemis evoking the Elektra of Euripides - but to the despondency of their respective conditions. Could the marital satisfaction desired by Chrysothemis be as equally destined for failure as Elektra's own attempt to bring her father back from the dead?

Another intriguing similarity between the sisters in the libretto concerns the role of imagination in each of their trajectories. The comparison, of course, is between Elektra's gruesome imagining of her revenge (in the monologue) - accompanied by a waltz - and the image of motherhood and marital bliss expounded by Chrysothemis in the duet. If Elektra's imagination is responsible for performing the dance of death that marks the success of her vengeful endeavor, Chrysothemis produces a fantasy of her own: pregnancy, bearing milk, and holding a child to her breast. Through these parallel fantasies, Hofmannsthal unites the sisters, suggesting that both are motivated by dreams of future satisfaction. The extent to which Elektra in fact achieves a lasting sense of accomplishment at the end of the work is not as clear. For our purposes here, however, it is enough to point out that fantasy drives the activities of both sisters. ${ }^{22}$

Hofmannsthal establishes a final textual parallel between Chrysothemis and Elektra at the conclusion of the duet. While Elektra's initial response to Chrysothemis' impassioned lament is to demand that she stop howling, her subsequent statement is even more telling. With cruelty, she asks her sister: "Stellen sie vielleicht für dich die Hochzeit an? Ich hör' sie laufen. Das ganze Haus ist auf. Sie kreissen, oder sie morden.” (“Could it be perhaps they've fixed your wedding day? I hear them running, the whole house is

\footnotetext{
${ }^{22}$ Wikshaland points out that in the concluding duet of between Chrysothemis and Elektra (after they have joined together in a common goal), the voices of the two women intertwine so closely and sensuously that they cannot be distinguished from one another without a score. This would seem to suggest evidence of the opposite of what I have argued here, namely, that Strauss' musical writing for the sisters can occasionally emphasize similarity rather than difference. Wikshaland, however, rightly qualifies the sisterly musical fusion: "But while the two voices merge completely, they remain at the same time the two distinctive voices of two different persons. (...) We might even say that the duet suggests that Chrysothemis forms the surviving, present half of the Elektra who haunts the opera as a specter from the past" (WIKSHALAND, 2007, p. 172).
} 
up. They're breeding, or they are murdering!') Hofmannsthal, here, openly appeals to the literary trope linking sex and marriage to death. Elektra knows full well that the household is preparing a sacrifice and taunts Chrysothemis by suggesting that these are arrangements for a wedding. Beyond allowing the marriage-death dyad to resonate through the text, Hofmannsthal's line foreshadows the conclusion of the play. As Elektra is about to die from vengeful ecstasy, she calls attention to the role of love and death in her life, claiming: "Ai! Liebe tötet! Aber keiner fährt dahin und hat die Liebe nicht gekannt!" ("Ai! Love is fatal! And no one dies without first making love's acquaintanceship.") This statement ensures that the question of marriage and death is not just a Chrysothemian concern, but one that is common to both sisters: if the thought of dying before marriage torments Chrysothemis, Elektra's marriage is death. Considering Elektra's near-orgasmic satisfaction at the success of her vengeful plot, expressed in dance, it is far from a stretch to identify grave and marriage bed in the opera's constellation of images. ${ }^{23}$

Strauss' music in the concluding section of the duet, once again, distinguishes rather than equates the sisters. Strauss concludes Chrysothemis' lament with a clear V-I cadence that exudes in finality, suggesting that the sisters - rather than conversing with one another - are speaking past each other. After the cadence, the musical idiom changes once again and Elektra barges in with her own voice in an attempt to musically obliterate the $19^{\text {th }}$ century fantasy her sister has just communicated. The reappearance of the hatred motif is followed by five forte accented staccato chords in the strings, which act as a violent interruption of Chrysothemis' lyricism. Here, once again, Strauss is going for contrast rather than subtlety. He captures the exclamatory tone of Elektra's speech in Hofmannsthal and transforms it into music without regard for the subtleties of the text. The overall structure of the scene, then, can be characterized as an ABA, where Elektra's initial aversion to her sister followed by Chrysothemis' plight leads only to more hatred and mockery on the part of the protagonist.

Strauss furthers his attempt to contrast Chrysothemis' music from that of the rest of the opera - including that of Elektra - by employing (in "Es geht ein Lärm los") a

\footnotetext{
${ }^{23}$ Rosaline Bonellier remarks on this connection with reference to Robert Carsen's mise-en-scène for the 2013 Opéra Bastille production of Elektra: "Dans la mise en scène de Robert Carsen, Électre, douloureusement, va se coucher sur la tombe comme sur un lit nuptial, indique même son intention de descendre rejoindre le mort dans sa tombe" (BONNELLIER, 2014, p. 166).
} 
succession of varied chords out of which surge the music of Klytämnestra. Norman del Mar claims that the passage aims to cause a complete tonal confusion in the mind of the listener, especially at the break-neck tempo in which it unfolds. This effect is intensified, says Del Mar, when the motifs are superimposed on one another, and Strauss plays upon this confusion through tone color and abrupt plunges into harmonic dissonance. ${ }^{24}$ No two musical passages could be more different, then, than Chrysothemis' lament and the concluding A section of the duet. Strauss then chooses to emphasize the conventionality of Chrysothemis' music, a solitary island of romanticism in the sea of dissonance that gushes from Elektra.

\section{Conclusion}

In this analysis, I have described a fundamental difference in how Hofmannsthal and Strauss approached the character of Chrysothemis in the opera Elektra. In one of the key scenes between the sisters ("Elektra!/Ich kann nicht sitzen und ins Dunkel starren/Es geht ein Lärm los"), I have shown 1) that a number of subtleties in Hofmannsthal's text are meant to bring the sisters together; 2) that these are often ignored or deemphasized by Strauss, who prefers to present the sisters in diametrically opposed poles with respect to the family tragedy. I have also shown that the imbalance of power between the sisters has to do, in part, with Elektra's dominance over the orchestra, which - throughout the work - is a musical double of her perspective on unfolding events, rather than an impartial "view from nowhere" that characterizes most representational leitmotifs.

Given instrumental music's power to shape perception of character in opera, it is perhaps natural that Strauss' musical interpretation of the characters should overpower that of Hofmannsthal. Nonetheless, careful attention to the nuances of the text - and how they are or are not reflected in Strauss' musical writing - can propose intriguing possibilities for performance of this scene. If the parallels between Chrysothemis and Elektra do not survive in the music, their presence in the text can perhaps be emphasized or reanimated through the help of direction, gesture, clothing, and scenery. By considering such moments of strain between music and text, thus, one can perhaps revivify the visual and dramatic conceptions of future stagings of Elektra.

\footnotetext{
${ }^{24}$ DEL MAR, 1962, p. 308.
} 


\section{Bibliography}

ABBATE, Carolyn. "Elektra's Voice: Music and Language in Elektra" in Richard Strauss: Elektra, ed. Derrick Puffett. Cambridge: Cambridge University Press, 1989, p. 107-27.

ADORNO, Theodor W. "Musik, Sprache, und ihr Verhältnis im gegenwärtigen Komponieren." Jahresing, Stuttgart, 1956, p. 56-57.

BAYERLEIN, Sonja. Die Drei Frauengestalten in der Opera Elektra. Tutzing: Hans Schneider, 1996.

BONNELLIER, Rosaline. "Le poète et l'opéra : à propos d'Elektra, tragédie en un acte d'Hugo von Hofmannsthal, musique de Richard Strauss (1909) », L'Esprit du temps, vol 129, no. 4, 2014, p. $159-170$.

CHESSICK, Richard. "On the Unique Impact of Richard Strauss' Elektra.” American Journal of Psychotherapy, Vol. XLII, no. 4, 1988, p. 585-596.

CRAFT, Robert. Current Convictions. New York: Alfred A. Knopf, 1977.

DAHLHAUS, Carl. Die Musik der 19. Jahrhunderts. Wiesbaden: Akademische Verllagsgesellschaft Athenaion, 1980, p. 291-293.

DEL MAR, Norman. Richard Strauss: A Critical Commentary on his Life and Works: Volume One. Ithaca: Cornell University Press, 1962.

KIVY, Peter. "Musical Morality." In Antithetical Arts: On the Ancient Quarrel between Literature and Music, 215-34. Oxford: Oxford University Press, 2009.

KRAMER, Lawrence. "Fin-de-siècle Fantasies: Elektra, Degeneration and Sexual Science." Cambridge Opera Journal, Vol. 5, No. 2, 1993, p. 141-165.

PUFFET, Kathryn Bailey. Derrick Puffet on Music. New York: Routledge, 2001.

PUFFETT, Derrick. "The Music of Elektra: Some Preliminary Thoughts" in Richard Strauss: Elektra. Cambridge: Cambridge University Press, 1989.

STRAUSS, Richard. Elektra. New York: Dover Publications, 1991, comp. 1906-8.

TARUSKIN, Richard. "The Danger of Music and the Case for Control." In The Danger of Music and Other Anti-Utopian Essays, 168-180. Berkeley: University of California Press, 2008.

WIKSHALAND, Stale. "Elektra's Oceanic Time: Voice and Identity in Richard Strauss." $19^{\text {th }}$ Century Music, vol. 31, no.2, 2007 p. 164-174. 